\title{
Misiune și pastorație individuală prin Taina Spovedaniei
}

\section{Cosmin-Cătălin LAZĂR}

Abstract: The Church's mission is to return man to communion with God. The individual ministry, through the confession sacrament, highlights the uniqueness of a person. The mission that a priest has through the confession sacrament is not limited only to the act itself, but extends on a longer period by the personal canon that the parishioner receives, by the direct relationship that he permanently has, through the Church, with the confessor priest. This direct and permanent relationship involves a continous fight with the sin, and, in the same time a change of the man. Taking into consideration all the above, it can be noticed that the priest's mission is a confessional one.

Keywords: mission, ministry, teaching, guidance, salvation.

\section{Misiunea Bisericii sau calea mântuirii}

Misiunea Bisericii are izvor nesecat în comuniunea de iubire veșnică a Sfintei Treimi ${ }^{1}$. Misiunea este o dimensiune și o componentă

${ }^{1}$ Valer Bel, Misiunea Bisericii în lumea contemporană, 1 Premise teologice, 
esențială a Bisericii². Rolul primordial al Bisericii în lume este de a face lucrarea răscumpărătoare a Mântuitorului ${ }^{3}$, sau altfel spus, ,,Biserica a fost întemeiată pentru slujire de insuși Domnul Iisus Hristos și ea trebuie să-L constituie mai departe aici pe pământ, atât din punct de vedere ființial-tainic, cât și din punct de vedere funcțional-vizibil".4. Misiunea constituie astfel o necesitate permanentă a Bisericii, ,un criteriu fundamental al Bisericii, nu numai în sensul că Biserica este instrumentul misiunii, ci și că ea, Biserica, este scopul sau realizarea misiunii"'.

Biserica fiind un organism viu și unitar, misiunea este unitară, prin faptul că toate sufletele sunt chemate la mântuire ${ }^{6}$, dar trebuie reținut că misiunea, adresându-se fiecărui credincios în parte, are și caracter individual.

În acest sens, Prefericitul Părinte Patriarh Daniel arată diferența dintre misiunea colectivă și cea individuală a Bisericii, spunând că:

„Trebuie să reţinem faptul că harul Duhului Sfânt lucrează prin duhovnic în modul cel mai personal fiindcă atunci când se predică, se predică mulţimii credincioşilor, dar la spovedanie este vorba de o relaţie personală a duhovnicului cu fiecare penitent şi aceasta arată că Ortodoxia ia în serios identitatea persoanei care are un chip şi un nume şi nu face dezlegări colectiviste unor persoane anonime, ci fiecare persoană are o destinaţie precisă în istoria mântuirii şi o vocaţie aparte, de aceea regulile

Cluj-Napoca, Presa Universitară Clujeană, 2004, p. 15.

${ }^{2}$ Idem, Misiunea Bisericii în iconomia Bisericii, în „Credință și viață în Hristos, Anuarul Episcopiei Sălajului”, Anul VI, 2013, Zalău, Edit. Episcopiei Sălajului, 2014, p. 478.

${ }^{3}$ Ibidem, p. 480-481.

${ }^{4}$ Aurel Pavel, Biserica misionară, în „Orizonturi teologice”, Volum omagial, Edit. Universității Oradea, Oradea, Edit. Buna Vestire Beiuș, 2001, p. 69.

${ }^{5}$ Ion Bria, Dicționar de Teologie Ortodoxă, București, Edit. Institutului Biblic și de Misiune al Bisericii Ortodoxe Române, 1981, p. 250.

${ }^{6}$ Vasile Coman, Scrieri de teologie liturgică și pastorală, Oradea, Edit. Episcopiei Române a Oradiei, 1983, p. 247-248. 
duhovniceşti nu se pot aplica în mod automat tuturor persoanelor, pentru că fiecare persoană este diferită. Pentru acelaşi păcat nu se dă canon identic la două persoane diferite ca vârstă, ca pregătire, ca înaintare duhovnicească, ci se ţine seama de specificul fiecărei persoane"

\section{Duhovnicul și dimensiunea duhovnicească a misiunii}

Dimensiunea duhovnicească a misiunii este indisolubil legată de dimensiunea ei liturgică, de mărturia prin sfințenia vieții, de transmiterea credinței celei adevărate prin predicarea Evangheliei și prin Tradiția vie a Bisericii. De asemenea, ea realizează legătura dintre cele trei momente ale ciclului credinței: mărturisire, celebrare, practicare. Aspectul duhovnicesc al vieții și gândirii creștine este o exigență fundamentală a misiunii, fără de care aceasta nu e decât vorbărie goală, fățărnicie și luarea numelui Domnului în deșert ${ }^{8}$.

Misiunea preotului prin excelență este călăuzirea duhovnicească a credincioşilor pe calea mântuirii, prin slujirea sa, preotul duhovnic devenind martor la viața fiecărui fiu duhovnicesc. Prin Taină Spovedaniei, preotul nu cunoaște doar starea de păcat sau nivelul duhovnicesc al credincioșilor săi, ci și problemele sociale și familiale, în aceste situații preotul putând interveni acolo unde este cazul și mai ales acolo unde i se cere să intervină.

Prin Taina Spovedaniei, preotul are misiunea de a veghea la sănătatea morală a credicioșilor, pe care îi are în păstorire, căci ,După cum medicul trupesc are grijă și răspunde de sănătatea și igiena localității în care activează, preotul răspunde în fața lui Dumnezeu și

${ }^{7} \mathrm{http} / / /$ ziarullumina.ro/11-preoti-au-primit-hirotesia-intru-duhovnic 102644. html, (Accesat Iulie 2, 2015).

${ }^{8}$ Grigore Dinu Moș, Dimensiunea duhovnicească a misiunii, în Ioan Chirilă (coord.), „Misiunea Bisericii în Sfânta Scriptură și în istorie, Biblie și multiculturalitate III", Cluj-Napoca, Edit. Renașterea, 2006, p. 99. 
a oameniloir de sănătatea morală a enoriașilor săi duhovnicești” " 9

Lupta duhovnicească a omului îşi are bază în Taina mărturisirii, prin care se permite ca Hristos să fie prezent şi să lucreze înlăuntrul omului. Prin aceasta lucrarea duhovnicească a preotului depăşeşte limitele psihologiei. Mai mult decât atât, întreaga misiune a preotului este una duhovnicească, misiunea preotului duhovnic nefiind alta decât aducerea omului înaintea lui Dumnezeu, gol de orice patimă și păcat.

În acest sens Rafail Noica spune că:

„Duhovnicia nu este psihologie, duhovnicia nu este viaţă trupească, duhovnicia nu este istoricitate sau istorie, duhovnicia nu este etică şi maniere sau manierisme. Duhovnicia este duh, şi «Duh este Dumnezeu» (In. 4, 24). Şi trebuie să găsim felul în care Dumnezeu acum poate să lucreze lucrarea de mântuire în fiecare suflet ce vine către mine şi pe care trebuie să-l aduc la Hristos" ${ }^{\prime 10}$.

Duhovnicia prin Sfânta Taină a Mărturisirii are o importanţă deosebită în lucrarea pastorală, întrucât prin intermediul ei preotul pătrunde în sufletul credinciosului, căci:

„Preoția se ocupă cu sufletul care-i din Dumnezeu și dumnezeiesc, care-i părtaș nobleței celei de sus și tinde spre noblețea aceea... Preoția, știința vindecării sufletelor, urmărește să într-aripeze sufletul, să-l smulgă din lume, să-l dea lui Dumnezeu. Preoția urmărește să facă să locuiască, prin Duhul Sfânt, Hristos în inimile oamenilor"11.

Spovedania, Pocăinţa sau Mărturisirea este „Taina renaşterii

\footnotetext{
${ }^{9}$ Ion Buga, Pastorala. Calea preotului, Ed. a II- a, Edit. Sfântul Gheorghe Vechi, 1999, p. 194.

${ }^{10}$ Rafail Noica, Cultura Duhului, Alba-Iulia, Edit. Reîntregirea, 2002, p. 43-44.

${ }^{11}$ Sfântul Grigorie din Nazianz, Cuvânt de apărare pentru fuga în Pont sau despre preoție, XVII, în „Despre preoție”, traducere, introducere și note de Pr. Dumitru Fecioru, București, Edit. Sofia, Edit. Biserica Ortodoxă, 2004, p. 223.
} 
duhovniceşti, a reînvierii, este al doilea Botez prin care se reface comuniunea cu Dumnezeu întreruptă prin încălcarea voii lui Dumnezeu cuprinsă în Legea morală"' ${ }^{\prime 2}$. Sfântul Simeon Noul Teolog consideră Sfânta Taină a Mărturisirii ca fiind ,al doilea Botez”, mărturisirea păcatelor fiind o curățire, prin care se oferă harul Duhului pe care 1-am primit la Botez ${ }^{13}$.

Taina Spovedaniei constă așadar în iertarea păcatelor celor ce se mărturisesc și se căiesc pentru ele, de către episcop sau preot - în mod văzut, și de către Hristos - în mod nevăzut ${ }^{14}$.

Cunoscute fiind cele trei dimensiuni ale preoției sacramentale, respectiv slujirea, propovăduirea și îndrumarea, și în Taina Spovedaniei lucrarea preotului este întreită.

La prima vedere credincioşii percep în Taina Spovedaniei numai dimensiunea pedagogică a acesteia, respectiv lucrarea de învăţător şi îndrumător a preotului, rolul de slujitor fiind foarte mult minimalizat, datorită faptului că majoritatea credincioșilor văd în cult un ritual complex, iar în ceea ce privește rânduiala propriu-zisă a Tainei Mărturisirii, ea este una relativ simplă.

Cum am văzut ceva mai sus, săvârşitorul Tainei Spovedaniei în chip nevăzut este Însuși Mântuitorul nostru Iisus Hristos, iar în chip văzut, arhiereii, precum și preoții duhovnici care au primit prin hirotesie puterea de a lega și dezlega păcatele. În acest sens, Sfântul Ioan Gură de Aur definește preoția ca fiind ,cea mai înaltă stare din câte ni s-au dăruit de Dumnezeu. Preoția nu se săvârșește pe pământ, are demnitatea lucrurilor cerești. Lor, preoților, li s-a dat să dispună

${ }^{12}$ Ioachim Pârvulescu, Sfânta Taină a Spovedaniei pe înțelesul tuturor, Mănăstirea Lainici-Gorj, 2000, p. 3.

${ }^{13}$ Marius Telea, Preoția și duhovnicia în viziunea Sfântului Simeon Noul Teolog, în „Orizonturi teologice”, Anul III, Nr. 3, Edit. Universităţii Oradea, 2003, p. 87-88.

${ }^{14}$ Dumitru Stăniloae, Teologia Dogmatică Ortodoxă, Vol. III, Ed. a III-a, București, Edit. Institului Biblic și de Misiune al Bisericii Ortodoxe Române, 2003, p. 127. 
de bunurile și au primit o putere, pe care Dumnezeu n-a dat-o nici îngerilor, nici arhanghelilor"15.

Preotul în Taina Mărturisirii este martorul necesar care ascultă mărturisirea, dar Dumnezeu este cel care o primeşte, duhovnicul fiind doar un mijlocitor după cum spune rugăciunea:

„Iată, fiule, Hristos, stă nevăzut, primind mărturisirea ta cea cu umilinţa. Deci nu te ruşina, nici nu te teme ca să ascunzi de mine vreun păcat, ci fără sfială spune toate câte ai făcut, ca să iei iertare, de la Domnul nostru Iisus Hristos. Iată, şi sfânta lui icoană este înaintea noastră. Iar eu sunt numai un martor, ca să mărturisesc înaintea Lui toate câte îmi vei spune mie; iar de vei ascunde de mine ceva, să ști că toate păcatele îndoite le vei avea, ia seama dar de vreme ce ai venit la doctor, să nu te întorci nevindecat" $"$.

Slujirea propriu-zisă a preotului în Taina Mărturisirii este dezlegarea păcatelor, căci „,preotul nu este numai slujitorul lui Dumnezeu, ci și slujitorul Bisericii și al mântuirii credincioșilor'”, iar în Taina Mărturisirii preotul slujește fiecărui suflet în parte și în același timp și lui Dumnezeu.

Părintele duhovnicesc nu este doar cel prin care se dă dezlegare de păcate, ci este cel care îndrumă pe credincios să aplice credinţa în viaţa concretă. Taina Sfintei Spovedanii este taina creşterii duhovniceşti, ea fiind o mare responsabilitate, dar şi un har deosebit, pentru că Dumnezeu inspiră pe preotul duhovnic să sfătuiască, să îndrume, să facă lumină în viaţa celui care se luptă să se ridice din

${ }^{15}$ Sfântul Ioan Gură de Aur, Tratatul despre preoție, în „Despre preoție”, traducere de Pr. Dumitru Fecioru, București, Edit. Sofia, Edit. Biserica Ortodoxă, 2004, p. 80.

${ }^{16}$ Molitfelnic, Bucureşti, Edit. Institului Biblic şi de Misiune al Bisericii Ortodoxe Române, 2006, p. 65.

${ }^{17}$ Dumitru Megheșan, Teologie și slujire în concepția Sfinților Trei Ierarhi, în „Orizonturi Teologice”, Anul II, Nr. 2, Oradea, Edit. Universității din Oradea/ Edit BunaVestire Beiuş, 2001, p. 36. 
păcat şi patimi, şi în acelaşi timp să crească duhovnicește. În acest sens este necesară o pregătire specială şi permanentă a duhovnicului ${ }^{18}$.

În ceea ce privește calitatea de îndrumător spiritual a preotului duhovnic în Sfânta Taina a Spovedaniei, se cere ca relaţia dintre preot şi credincios să fie o relaţie specială, o prietenie specială din care nu trebuie să lipsească încrederea şi buna cuviinţă. Prietenia aceasta trebuie să fie una sfinţitoare, prin care să-L găsim pe Dumnezeu.

Taina Spovedaniei apropie cel mai mult pe preot de credincioşii săi. Prin Taina Mărturisirii se dă posibilitatea preotului duhovnic să înveţe permanent exerciţiul vocaţiei de prieten, mai ales în societatea aceasta modernă, care devine din ce în ce mai mult o societate a izolării şi înstrăinării persoanei, o societate care oferă mijloace facile pentru a cultiva o prietenie virtuală. Oamenii au nevoie permanent de prieteni şi de a comunica cu ei în mod real. Prin aceasta preotul are calitatea de duhovnic, de născător întru Hristos, printr-o paternitate în adevăratul sens al cuvântului, și nu în înțeles metaforic sau legalist ${ }^{19}$. $\mathrm{O}$ astfel de relație părinte-fiu duhovnicesc presupune și rugăciunea reciprocă, deoarece lupta cu păcatul nu este doar a penitentului ci și a duhovnicului.

Prin toate acestea se arată de fapt importanța de căpătâi a Sfintei Spovedanii în pastoraţia individuală, căci în Taina Mărturisirii se scoate în evidenţă unicitatea persoanei.

Pastorația individuala prin Taina Mărturisirii nu se limitează numai la scaunul spovedaniei, ci se extinde pe o perioadă mai lungă, prin canonul personal pe care credinciosul îl primeşte la Spovedanie, dar şi prin relaţia directă şi unică pe care o are permanent, prin Biserică, cu preotul duhovnic, de la care credinciosul are datoria să-i ceară sfatul nu doar în scaunul mărturisirii ci și în alte momente.

\footnotetext{
$18 \mathrm{http}: / / z i a r u l l u m i n a . r o / 11-p r e o t i-a u-p r i m i t-h i r o t e s i a-i n t r u-d u h o v n i c-102644$. html, (Accesat Iulie 2, 2015).

${ }^{19}$ Andrei Andreicuț, Spovedanie și comuniune, Cluj-Napoca, Edit. Renașterea, Ediția a II- a, 2011, p. 121.
} 
Doar printr-o relaţie directă şi permanentă dintre preot şi credincios, se poate duce lupta continuă cu păcatul, şi în acelaşi timp se poate ajunge la o schimbare reală în vederea mântuirii.

In Taina Mărturisirii preotul este propovăduitor al Cuvântului lui Dumnezeu, căci el călăuzește pe credincioși după învăţătura lui Hristos. Misiunea de a propovădui cuvântul lui Dumnezeu oamenilor „,cu timp și fără timp” este una din datoriile principale ale preotului ${ }^{20}$. În acest sens ,, duhovnicului i se cere să fie în stare, prin citiri de cărți duhovnicești, prin urmărirea diferitelor procese psihologice, prin experiență, nu numai să dea cu o anumită siguranță sfaturile cele mai eficiente, ci să le și argumenteze în fața penitentului, ca acesta sa fie convins să le urmeze" ${ }_{21}$, iar aceste sfaturi întotdeauna trebuie argumentate pe baza învățăturii de credință.

Prin Taina Mărturisirii preotul duhovnic poate fixa anumite învățături de credință, dar poate observa și lipsurile credincioșilor săi în ceea ce privește cunoașterea învățăturii de credință, putând lua măsurile necesare în astfel de situații.

Așadar, din cele arătate, tragem concluzia că cel mai efectiv mijloc pentru refacerea vieții duhovnicești rămâne Sfânta Taină a Mărturisirii, aceasta având importanță de căpătâi în pastorația individuală a credincioșilor.

\section{Bibliografie}

1. *** Molitfelnic, Bucureşti, Edit. Institului Biblic și de Misiune al Bisericii Ortodoxe Române, 2006.

2. Andreicuț, Andrei, Spovedanie și comuniune, Cluj-Napoca, Edit. Renaşterea, Ediția a II- a, 2011.

3. Bel, Valer, Misiunea Bisericii în iconomia Bisericii, în „Credință

${ }^{20}$ Vasile Coman, Slujind lui Dumnezeu slujim oamenilor. Culegere de cuvântări și articole, Ed. a II-a, Edit. Episcopiei Ortodoxe Române a Oradiei, 1984, p. 5.

${ }^{21}$ Dumitru Stăniloae, op. cit., p. 140. 
şi viață în Hristos, Anuarul Episcopiei Sălajului”, Anul VI, 2013, Edit. Episcopiei, Zalău, 2014, p. 477-488.

4. Bel, Valer, Misiunea Bisericii în lumea contemporană, 1 Premise teologice, Cluj-Napoca, Presa Universitară Clujeană, 2004.

5. Bria, Ion, Dicționar de Teologie Ortodoxă, București, Edit. Institului Biblic și de Misiune al Bisericii Ortodoxe Române, 1981.

6. Buga, Ion, Pastorala. Calea preotului, Ed. a II- a, Edit. Sfântul Gheorghe - Vechi, 1999.

7. Coman, Vasile, Scrieri de teologie liturgică și pastorală, Oradea, Edit. Episcopiei Române a Oradiei, 1983.

8. Coman, Vasile, Slujind lui Dumnezeu slujim oamenilor. Culegere de cuvântări și articole, Ed. a II-a, Edit. Episcopiei Ortodoxe Române a Oradiei, 1984.

9. Megheșan, Dumitru, Teologie și slujire în concepția Sfinților Trei Ierarhi, în „Orizonturi Teologice”, Anul II, Nr. 2, Oradea, Edit. Universităţii din Oradea, Edit BunaVestire Beiuş, 2001, p. 26-39.

10. Moș, Grigore Dinu, Dimensiunea duhovnicească a misiunii, în Chirilă Ioan (Coord.), „Misiunea Bisericii în Sfânta Scriptură şi în istorie, Biblie și multiculturalitate III", Cluj-Napoca, Edit. Renașterea, 2006, p. 98-122.

11. Noica, Rafail, Cultura Duhului, Alba Iulia, Edit. Reîntregirea, 2002.

12. Pârvulescu, Ioachim, Sfânta Taină a Spovedaniei pe ințelesul tuturor, Mănăstirea Lainici-Gorj, 2000.

13. Pavel, Aurel, Biserica misionară, în „Orizonturi teologice”, Volum omagial, Oradea, Edit. Universității Oradea, Edit. Buna Vestire Beiuş, 2001, p. 80-92.

14. Sfântul Grigorie din Nazianz, Cuvânt de apărare pentru fuga in Pont sau despre preoție, XVII, în Despre preoție, traducere, introducere și note de Pr. Dumitru Fecioru, București, Edit. Sofia, Edit. Biserica Ortodoxă, 2004.

15. Sfântul Ioan Gură de Aur, Tratatul despre preoție, în Despre preoție, traducere de Pr. Dumitru Fecioru, București, Edit. Sofia, Edit. Biserica Ortodoxă, 2004.

16. Stăniloae, Dumitru, Teologia Dogmatică Ortodoxă, Vol. III, Ed. a III-a, București, Edit. Institutului Biblic și de Misiune al 
Bisericii Ortodoxe Române, 2003.

17. Telea, Marius, Preoția și duhovnicia în viziunea Sfântului Simeon Noul Teolog, în „Orizonturi teologice”, Anul III, Nr. 3, Universitatea din Oradea, Facultatea de Teologie Ortodoxă, Oradea, Edit. Universităţii Oradea, 2003, p. 83-95.

\section{Surse web}

http://ziarullumina.ro/11-preoti-au-primit-hirotesia-intruduhovnic-102644.html, (Accesat Iulie 2, 2015). 